\title{
栽植様式が小ギクの開花斉一性に及ぼす影響
}

\author{
仲 照史 ${ }^{1,2 *} \cdot$ 前田茂一 ${ }^{1} \cdot$ 後藤丹十郎 $2^{2}$ \\ 1 奈良県農業研究開発センター 634-0813 奈良県橿原市四条町 \\ 2 岡山大学大学院環境生命科学研究科 700-8530 岡山県岡山市北区津島中
}

\section{Effects of Planting System on Flowering Period Uniformity of Small-flowered Spray-type Chrysanthemum}

\author{
Terufumi Naka ${ }^{1,2 *}$, Shigeichi Maeda ${ }^{1}$ and Tanjuro Goto ${ }^{2}$ \\ ${ }^{I}$ Nara Prefectural Agricultural Research and Development Station, Shijocho, Kashihara, Nara 634-0813 \\ ${ }^{2}$ Graduate School of Environmental and Life Science, Okayama University, Tsushima-naka, Kitaku, Okayama 700-8530
}

\begin{abstract}
For simultaneous mechanical harvesting of small-flowered spray-type chrysanthemum, the effects of planting systems on flowering period uniformity were studied using the summer-autumn-flowering-type cultivar 'Okinamaru'. The influence on flowering periods of the planting position in the plant population, which were made up of six rows and seven columns, and the branching node number after pinching were investigated. Flowering periods in the edge rows facing north or south furrows were shorter than in the inner four rows. The difference in the photosynthetic photon flux density of the plant community at the canopy height from about $15 \mathrm{~cm}$ below the canopy was smaller for the inner rows than for the edge rows. These results demonstrate that more solar radiation reached the lower leaves of the inner rows. In the three shoots remaining after pinching, shoots from the lower lateral node showed a longer flowering period, but no significant difference was noted between those of upper shoots and middle shoots. In the next three experiments, changing the center inter-row distance, shading around the plant population and pinching were examined to improve the uniformity of flowering. In the first experiment, using the plant population planted north to south in four rows, the center inter-row distance was changed from 15 to $90 \mathrm{~cm}$. Flowering periods of the inner and outer two rows were respectively measured. The difference in flowering periods between those of the inner and outer two rows decreased as the center inter-row distance increased. This was not significant for a more than $75 \mathrm{~cm}$ spacing. In the second experiment, shading materials with a $31 \%$ shading rate were suspended beside the edge rows under the ten-row condition, and the flowering period of each row was measured. The flowering periods of edge rows were slightly delayed by the shading treatment, but the flowering period uniformity was not improved markedly. In the third experiment, non-pinching, leaving a shoot per plant after pinching, and leaving two shoots per plant were compared under the four-row condition. Flowering period uniformity was improved in the two pinched experiment plots. In conclusion, spacing the center inter-row distance and training one or two shoots per plant improve the flowering period uniformity, which was influenced by the planting position and branching position after pinching.
\end{abstract}

Key Words : light environment, pinching, shade avoidance, summer-autumn-flowering-type chrysanthemum, uniform flowering

キーワード : 避陰反応，光環境，一斉開花，夏秋ギク，摘心

\section{緒言 \\ 我が国の切り花キク生産は電照や加温によって施設周年 化が進んできたが，小ギクに打いては依然として露地での 生産が中心となっている. こうした露地小ギク生産では生 産者数の減少が続く一方，苗生産の分業化や重量式選花機}

2016 年 1 月 18 日 受付. 2016年 6 月 23 日 受理.

本研究の一部は, 園芸学会平成 16 年度春季大会抒よび平成 17

年度近畿支部大会で発表した.

* Corresponding author. E-mail: naka@naranougi.jp
の導入などにより企業的農家による規模拡大が進んでお り, 経営面積 2〜3 ha といら生産者もみられるようになっ てきている（富山，2012）。

小ギク生産では，全労働時間の約半分を収穫・調製作業 が占めて抢り，その省力化は労働コスト削減と規模拡大の 鍵となる（仲，2011）。露地生産で規模拡大が進んでいる キャベッでは，収穫機の開発（青木，2013; 山本，1997） と併行して，生育の斉一性向上に関わる品種（藤原ら, 2003; 吉秋ら，2008）, 作型や栽植様式の影響（藤原ら, 2000，2003）が検討されてきた結果，一斉機械収穫による 低コスト化の実現が期待される状況となっている（天野, 
2006). 小ギクに括いても, 収穫機（田中，2012; 山本 ら，2014）や開花程度による切り花選別機（Fukumoto ら, 2011; 仲ら，2014）などの研究が進められて拉り, これら の実用化には栽培面からも開花斉一性を高める技術開発が 必要となっている.

キクの開花期は主として日長と気温によって決定される （川田ら，1987）が，生産現場に抢ける小ギクの收穫期間 は秋ギク型品種でも 1 週間前後, 夏秋ギク型品種では 3 週 間以上にわたる場合もある。このことは, 畧やべッドに群 落として栽培された各シュートの開花日に日長と気温以外 の要因が影響していることを示唆して和り，これまでにも 親株個体群の系統分離や苗の温度履歷（仲ら, 2016), 栄 養成長期の草勢（本間，1999）なぞの影響が指摘されてい る。また，スプレーギクに执いても栽植密度拉よび光条件 と生育量のモデル化を検討した報告の中で, 光合成有効光 量子束密度（以下, PPFD）の増加が到花日数の斉一性を 高め (Karlsson ら, 1989), 栽植密度が高い注ど到花日数 の分散が大きくなる (Langtonら，1999）とされている.さ らに本間（2000）は，輪ギク ‘秀芳の力’ の電照作型に括 いて条間を拡げることで開花日が集中化できると報告して おり, 栽植様式とこれに連動した光環境の変更が開花の斉 一性に関与している可能性が考兄られる。

我が国の小ギク生産は, 自然開花期の異なる品種を組み 合わせる夏秋期生産と電照抑制による沖縄での冬春期生産 に大別される。 これらの作型では各々, 産地背景によって 様々な栽植様式が用いられている. 主な栽植様式として, 夏秋期生産では奈良県など西南暖地に拈ける 2 条植兄摘心 栽培, 岩手県など東日本に抢汀る 1 条植光摘心栽培, 冬春 期生産では沖縄県に打ける $4 \sim 5$ 条植えの摘心打上び無摘 心栽培が挙げられる。また，施設スプレーギク生産では小 ギクに類似した栽植様式のほか, 8 10 条植兄の無摘心栽 培も行われている。 その一方, こうした栽植様式が群落内 の光環境や生育開花に及洔す影響については, 切り花重な ぞ切り花形質との関係（池田ら，2006; 中村ら，2008; 佐 本ら，1979）について少数の報告があるものの, 開花の斉 一性に着目した研究は本間（1999）以外には久られない.

そこで本研究では, 収穫機による一斉収穫を目指寸ら光 で必要となる開花斉一性に関わる要因を明らかにするた め, 開花日のばらつきを群落内の栽植位置と摘心後分枝位 置に着目して整理した（実験 1). 次に，ここで観察され た群落周縁部と群落内部との開花日の差を解消寸るための 方法として, 群落の内側に中央条間を設ける方法（実験 2) と通路に面した群落側面に部分的な遮光を行ら方法（実験 3）について検討した. 加えて, 摘心と仕立て本数が開花 斉一性に及ぼす影響を, 同一の単位面積当たり立茎数で検 討した（実験 4).

\section{材料および方法}

\section{1. 共通の実験方法}

いずれの実験も，香川県善通寺市の農業・食品産業技術 総合研究機構近畿中国四国農業研究センター四国研究セン タ一内の圃場で行った。 供試品種には, 開花が不斉一にな りやすい夏秋ギク型品種（仲ら，2007）のらち, 西南暖地 に抢ける自然開花期が 7〜8 月で暗期中断による開花抑制 が可能な小ギク品種 “翁丸”（角川ら，2007）を用いた. 培養土 (Metro-mix\#350, Sun Gro Horticulture Distribution) を充填した 200 穴セルトレーに採穂当日に扦し芽し，無加 温ガラス温室内の間欠ミスト下で約 3 週間育苗した発根苗 を用いた、いずれの実験に打いても本圃の土性は砂壤土 で，施肥量は $\mathrm{N}: \mathrm{P}_{2} \mathrm{O}_{5}: \mathrm{K}_{2} \mathrm{O}$ を $2.1: 2.2: 2.2 \mathrm{~kg} ・ \mathrm{a}^{-1}$ とし，全 量を元肥として全層施用した.

灌水は, 土壤水分の不均一を最小化するため， 2 条に 1 本ずつ株元に配置した点滴チューブ（流滴 10 , ネタフィ ムジャパン(株)）から 1 日に $1 \sim 2$ 回行った.

切り花調査では, 最も開花の進んだ頭花の最外周の管状 花が開裂した時を開花日とし，開花日に分枝基部から収穫 して切り花長, 切り花重抢よび節数を記録した.

\section{2. 栽植位置と摘心後分枝の発生節位の影響（実験 1）}

深夜 6 時間（21:00３:00）の暗期中断下で管理した親 株から，2003 年 5 月 16 日に採穂して育苗を開始した。 こ こから生育の揃った挿し芽苗を 6 月 3 日に定植し，6月 10 日に本葉 4 枚で摘心した. 7 月 2 日に 4 本以上のシュート が発生した株は, 生育の劣るシュートを切除して 3 本に整 枝し，2 本以下の株は無整枝とした.

定植は，寒冷紗により $50 \%$ 遮光とした硬質プラスチッ クフィルムハウス内に設置した幅 $80 \mathrm{~cm}$ ，長さ $240 \mathrm{~cm}$ の東 西に長い栽培ベッドに，株間と条間をいずれも $12 \mathrm{~cm}$ とし て南北 6 条, 東西 20 列の群落として行った. 試験区はべッ ド中央に 6 条 7 列で 42 株の群落になるよら配置した（第 1 図). 調查対象外として, 試験区の西側には“翁丸” 36 株 を，東側には他品種 42 株をそれぞれ定植した，各定植位 置には，北から条番号を，東から列番号を付した，収穫時 には発生節位を確認して上位節から上位，中位抒よび下位 と区分した．な拉，摘心後分枝が 2 本であった株について は上位と中位として，1本であった株については上位とし て集計した。定植から 7 月 23 日までは $2.5 \mathrm{~m}^{2}$ 当たり 1 灯 の $60 \mathrm{~W}$ 白熱灯による深夜 6 時間の暗期中断を行い, 消灯 日に展開節数を調查した．各分枝の開花日に条番号，列番 号抢よび節位を確認して收檴し, 切り花調査を行った.

また, 群落内の受光量のばらつきを生育中期の 7 月 3 日 から 8 月 13 日までの 42 日間, 群落内で継続的に測定した. 測定は, 最も生育旺盛なシュートで形成される群落上面か ら約 $5 \mathrm{~cm}$ 下（群落上層部）と約 $15 \mathrm{~cm}$ 下（群落中層部） の 2 階層で, 各々飞北側 $1 \sim 2$ 条目, 中央部 $3 \sim 4$ 条目抢 よび南側 $5 \sim 6$ 条目の条間に, 計 6 基の光量子七ンサー 
（IKS-27，（株）小系製作所）を配置して行った。な拈，群 落上層部と群落中層部とした測定高は各々, 最も生育旺盛 なシュートと最も生育の遅れているシュートの最上位展開 葉付近に相当し, 植物の成長に合わせて随時, 高さを調節 した.

さらに, 群落内の光質を波長別光エネルギー測定装置 (LI-1800, Licor Inc.) によって，晴天日の 7 月 31 日南中時 に測定した. 測定点は北側の $1 \sim 2$ 条目, 中央部の $3 \sim 4$ 条目拈よび南側の 5〜6条目の条間に拈いて, 群落上面, 上面から約 $30 \mathrm{~cm}$ 下位の群落中層打よび約 $60 \mathrm{~cm}$ 下位の群 落下層とした。測定波長は350〜 $1100 \mathrm{~nm}$ の範囲で $10 \mathrm{~nm}$ ごととし，400～500 nm, 600～700 nm および $700 〜 800 \mathrm{~nm}$ を青色光 $(\mathrm{B})$, 赤色光 $(\mathrm{R})$ 扎よび遠赤色光 $(\mathrm{FR})$ として積 算した.

\section{4 条植えでの中央条間の影響（実験 2)}

実験には，各区 40 株を供試した。無加温ハウスで養成 した親株から採穂, 育苗した苗を2005 年 4 月 21 日に雨除 けハウスに定植し, 自然日長下で栽培した。 4 月 30 日に 摘心し，5月 23 日に株当たり 2 本に整枝した.

試験区は第 2 図のよらに複 2 条の 4 条植えの南北畧とし, 中央条間を $15,30,45,60,75$ 打よび $90 \mathrm{~cm}$ の 6 水準とし

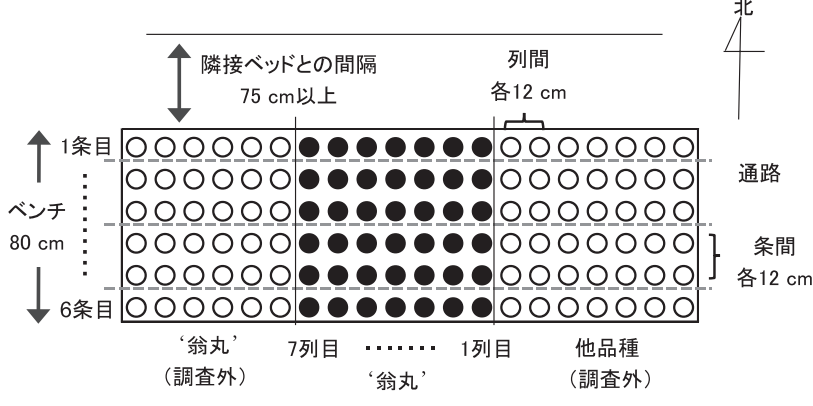

第 1 図試験区の栽植方法（実験 1)

図中の破線は，点滴チューブの敷設位置

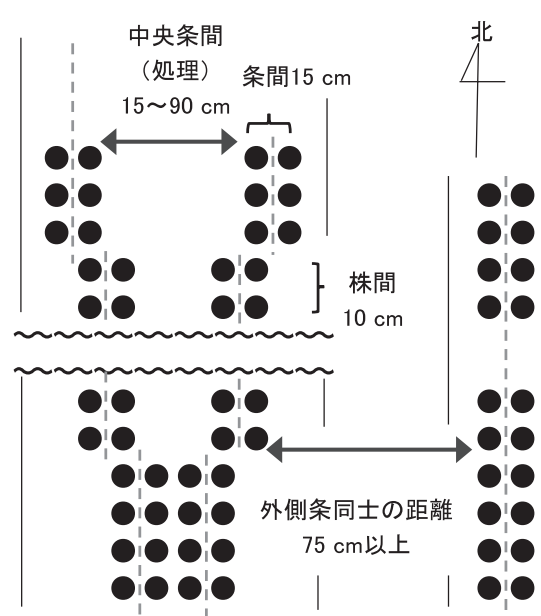

第 2 図 中央条間の異なる試験区の栽植方法（実験 2） 図中の破線は, 点滴チューブの敷設位置
た. 各区とも株間は $10 \mathrm{~cm}$, 東西各 2 条の条間は $15 \mathrm{~cm}$ と, 通路をはさんだ隣接畧の外側条同士の距離は $75 \mathrm{~cm}$ 以上を 確保した．各試験区の両端にあたる 8 株を除外した各区 32 株について, 栽植位置を確認したらえで切り花調査を 行った.

4. 植え付け条数と群落側面の遮光の影響（実験 3）

実験には，各区 100 株を供試した。無加温ハウスで養成 した親株から採穂，育苗した苗を2005年 4 月 21 日に雨除 けハウスに定植し，自然日長下で栽培した。 4 月 30 日に 摘心し，5月 23 日に株当たり 2 本に整枝した.

試験区は株間 $10 \mathrm{~cm}$ ，条間 $15 \mathrm{~cm}$ の 10 条植えとした 10 条区，同様の 10 条植えでフラワーネットの通路に面した 群落側面に遮光資材を $40 \mathrm{~cm}$ 下垂させた 10 条遮光区，株 間 $10 \mathrm{~cm}$, 条間 $15 \mathrm{~cm}$, 中央条間 $30 \mathrm{~cm}$ とした複 2 条の 4 条 植えとした 4 条区の 3 区を設けた。 フラワーネットは群落 上面から約 $20 \mathrm{~cm}$ 下位になるよう，生育に合わせて随時引 き上げた．各試験区の両端を除いた 80 株について，栽植 位置を西端から数えた条番号によって確認したらえで切り 花調査を行った.

な敃遮光資材には，群落周縁部の葉による遮蔽を模する ことを意図し, 赤色光吸収型フィルム（ブルースカイ, MKV プラテック（株））を用いた。処理に先だって，本資 材の光透過率を波長別光エネルギー測定装置（LI-1800， Licor Inc.）によって，晴天日（2004 年 12 月 17 日）の太陽 光下で実測した．本資材の PPFD $(400 \sim 700 \mathrm{~nm})$ ，赤色光 （600～700 nm） 扎よび遠赤色光（700～800 nm）の波長別 光透過率は各々 69,57 抢よび $71 \%$ であり，遮光下での赤 色光と遠赤色光の比率（以下, R/FR 比とする）は無処理 の 1.03 に対し 0.82 であった.

\section{5. 摘心の影響（実験 4）}

実験には，各区 100 株を供試した。無加温ハウスで養成 した親株から採穂，育苗した苗を2005 年 4 月 21 日に雨除 けハウスに定植し，自然日長下で栽培した。

試験区は株間 $15 \mathrm{~cm}$ ，条間 $15 \mathrm{~cm}$ ，中央条間 $30 \mathrm{~cm}$ とした 複 2 条の 4 条植えで株当たり 2 本に整枝した 2 本整枝区, 株間 $7.5 \mathrm{~cm}$, 条間 $15 \mathrm{~cm}$, 中央条間 $30 \mathrm{~cm}$ とした複 2 条の 4 条植えで株当たり 1 本に整枝した 1 本整枝区， 1 本整枝区 と同じ栽植様式で摘心を行わない無摘心区の 3 区とした. いずれの試験区も栽植面積当たりの立茥数は 71 本・ $\mathrm{m}^{-2}$ と した. 無摘心区以外の 2 区は 4 月 30 日に摘心し，5月 23 日に整枝した． 2 本整枝区は 20 株， 1 本整枝区と無摘心区 は各 40 株について切り花調査を行った.

\section{結果}

\section{1. 栽植位置と摘心後分枝の発生節位の影響（実験 1）}

群落として栽培した時の栽植位置が消灯後到花日数に及 ぼす影響を，南北位置と東西位置に分けて第3図に示した. 南北位置を示す条ごとの消灯後到花日数についてみると, 群落中央の $2 \sim 5$ 条目間には有意差が見られなかった一方， 

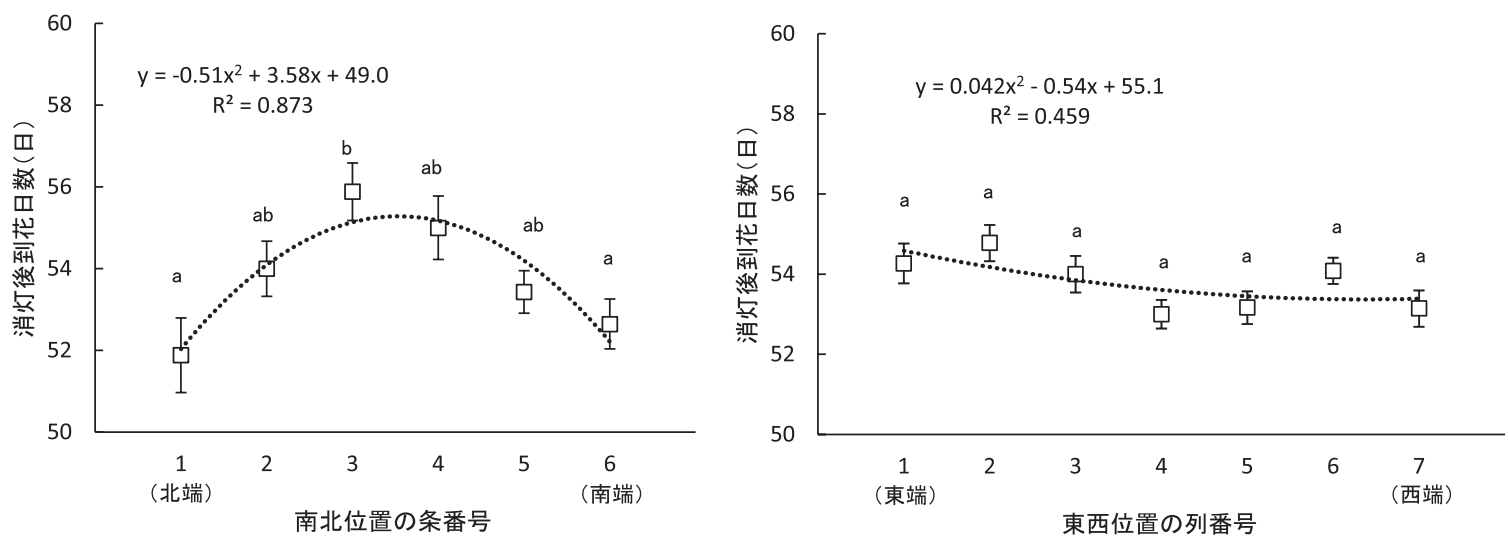

第3 図小ギク ‘翁丸’に打ける群落内での栽植位置が消灯後到花日数に及ぼす影響（左：南北位置，右：東西位置） 図中の曲線は二次近似式，䛊差範囲は標準䛊差 $(n=9 \sim 17)$

南北位置と東西位置の各々について，異なる英小文字間に Tukey-Kramer の HSD 検定により 5\%水準で有意差のあること を示す

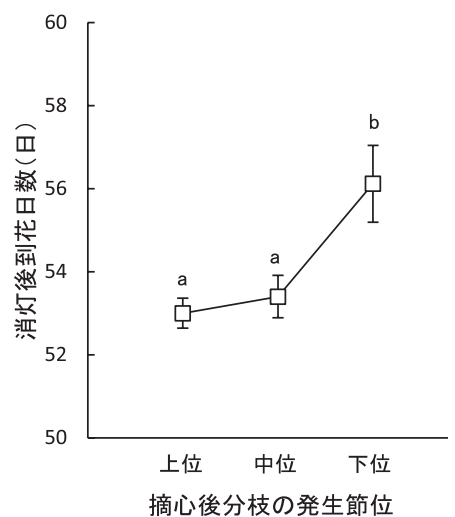

第 4 図 小ギク ‘翁丸’に打忊摘心後分枝の発生節位が消灯 後到花日数に及ぼす影響

誤差範囲は標準誤差（ $\mathrm{n}=17 ４ 0 ）$

異なる英小文字間に Tukey-Kramerの HSD 検定により $5 \%$ 水準で有意差あり

南北両側の周縁部に位置するシュートの消灯後到花日数は 群落中央より短く，これらの関係は上に凸な二次曲線で良 く近似できた，一方，両側を群落にはさまれている東西位 置についてみると，列ごとの消灯後到花日数はほぼ一定と なった。

摘心後の分枝位置が消灯後到花日数に及ぼす影響を第 4 図に示した，上位節执よび中位節と比較して，下位節では 消灯後到花日数が長くなり，そのばらつきも大きかった。

栽植位置と分枝発生節位が切り花長, 切り花重㧍よび節 数に及ぼす影響を第 1 表に示した。栽植位置の影響は消灯 後到花日数と同様, 南北周縁部に特徵的にみられ, 群落内 部に比べて切り花長が短く, 切り花重が重くなった. 一方, 開花時と消灯時のいずれの節数にも栽植位置による差はな かった，分枝発生節位については，上位節活ど開花時節数 と消灯時節数がともに多くなったが, 切り花長と切り花重 には有意差がみられなかった。

これら群落全体の切り花重扣よび消灯時節数と消灯後到
第 1 表 群落内の栽植位置と分枝発生節位が小ギク “翁丸’の 切り花長, 切り花重および節数に及ぼす影響

\begin{tabular}{|c|c|c|c|c|}
\hline $\begin{array}{l}\text { 栽植位置と } \\
\text { 分枝発生節位 }{ }^{\mathrm{z}}\end{array}$ & $\begin{array}{c}\text { 切り花長 } \\
(\mathrm{cm})\end{array}$ & $\begin{array}{c}\text { 切り花重 } \\
(\mathrm{g})\end{array}$ & $\begin{array}{c}\text { 開花時 } \\
\text { 節数 } \\
\text { (節) }\end{array}$ & $\begin{array}{c}\text { 消灯時 } \\
\text { 節数 } \\
\text { (節) }\end{array}$ \\
\hline \multicolumn{5}{|c|}{ 南北位置（北端が 1 条目） } \\
\hline 1 & $108 \mathrm{a}^{\mathrm{y}}$ & $71 \mathrm{bc}$ & 46 a & $24 \mathrm{a}$ \\
\hline 2 & $113 \mathrm{~b}$ & $41 \mathrm{a}$ & $45 \mathrm{a}$ & $23 \mathrm{a}$ \\
\hline 3 & $115 \mathrm{~b}$ & $37 \mathrm{a}$ & 44 a & $22 \mathrm{a}$ \\
\hline 4 & $116 \mathrm{~b}$ & $42 \mathrm{a}$ & $44 \mathrm{a}$ & $22 \mathrm{a}$ \\
\hline 5 & $115 \mathrm{~b}$ & $55 \mathrm{ab}$ & $47 \mathrm{a}$ & $24 \mathrm{a}$ \\
\hline 6 & $109 \mathrm{a}$ & $89 \mathrm{c}$ & $44 \mathrm{a}$ & $23 \mathrm{a}$ \\
\hline \multicolumn{5}{|c|}{ 東西位置（東端が 1列目） } \\
\hline 1 & $114 \mathrm{a}$ & 58 a & $45 \mathrm{a}$ & $23 \mathrm{a}$ \\
\hline 2 & $111 \mathrm{a}$ & $54 \mathrm{a}$ & $44 \mathrm{a}$ & $23 \mathrm{a}$ \\
\hline 3 & $111 \mathrm{a}$ & $46 \mathrm{a}$ & 44 a & $22 \mathrm{a}$ \\
\hline 4 & $112 \mathrm{a}$ & $64 \mathrm{a}$ & $46 \mathrm{a}$ & $24 \mathrm{a}$ \\
\hline 5 & $113 \mathrm{a}$ & 59 a & $45 \mathrm{a}$ & $23 \mathrm{a}$ \\
\hline 6 & $113 \mathrm{a}$ & 53 a & $44 \mathrm{a}$ & $23 \mathrm{a}$ \\
\hline 7 & $112 \mathrm{a}$ & $65 \mathrm{a}$ & $46 \mathrm{a}$ & $23 \mathrm{a}$ \\
\hline \multicolumn{5}{|l|}{ 分枝発生節位 } \\
\hline 上位 & $113 \mathrm{a}$ & $61 \mathrm{a}$ & $47 \mathrm{c}$ & $24 \mathrm{~b}$ \\
\hline 中位 & $112 \mathrm{a}$ & 59 a & $45 \mathrm{~b}$ & $23 \mathrm{~b}$ \\
\hline 下位 & $111 \mathrm{a}$ & $44 \mathrm{a}$ & $42 \mathrm{a}$ & $21 \mathrm{a}$ \\
\hline
\end{tabular}

$\mathrm{z}$ 南北位置, 東西位置抒よび分枝発生節位の標本数は各々, $\mathrm{n}=10 \sim 17,9 \sim 15$ 打よび $17 \sim 40$

$\mathrm{y}$ 南北位置, 東西位置执よび分枝発生節位各々飞扔いて，同 一列の異なる英小文字間に Tukey-Kramer の HSD 検定によ り，5\%水準で有意差のあることを示す

花日数の間には，第 5 図に示したように消灯時節数が多い ほぞ，また切り花重が重いほど到花日数が短い負の相関が みられた。

群落内の南北位置と上下位置別に測定したPPFD の日変 化を第 6 図に示した．群落上層部では，南側でやや大きく 推移し，北側と中央の差は小さかった。一方，群落中層部 では南側で小さく推移し，北側と中央の差は小さかった. 

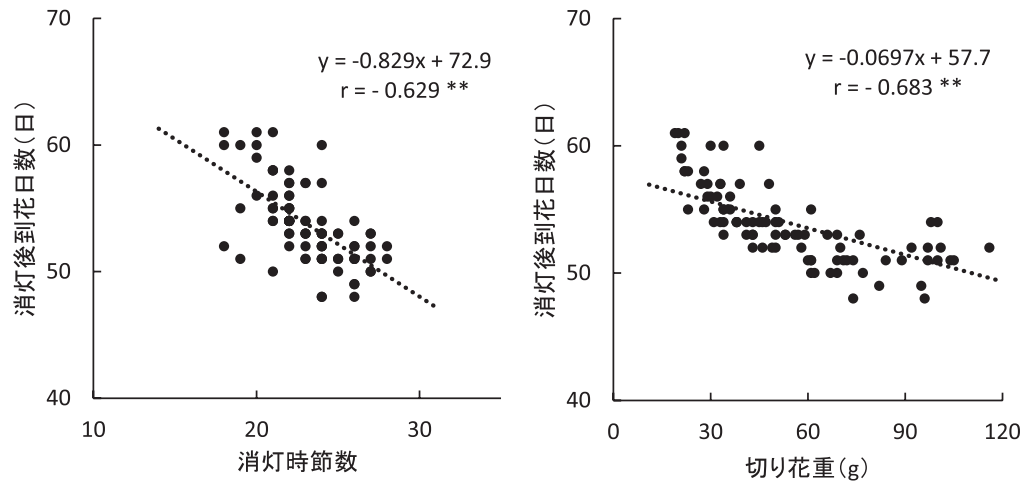

第 5 図 消灯時節数（左）および切り花重（右）と消灯後到花日数の相関（実験 1） 図中の点線抢よび数式は, 最小自乗法による回帰直線を示す **は $1 \%$ 有意

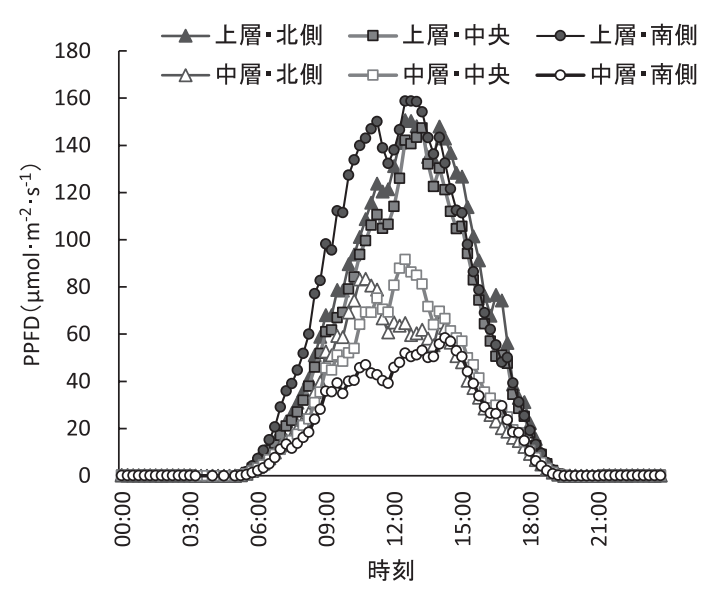

第 6 図 小ギク群落内の南北位置と上下位置による受光量の 違い

測定期間（2003 年 7 月 3 日 8 月 13 日）の平均值 上層と中層は各々, 群落上面から約 $5 \mathrm{~cm}$ 下と約 $15 \mathrm{~cm}$ 下で. 北側，中央拈よび南側は各々，北側 $1 \sim 2$ 条目, 中央部 $3 \sim 4$ 条目打よび南側 $5 \sim 6$ 条目の条間で光合成 有効光量子束密度（PPFD）を測定した

また，群落内での波長別光量子束密度の分布を第 2 表に示 した. R/FR 比は群落上面に拈いて $1.05 〜 1.07$ であったの に対し，群落中層では $0.51 \sim 0.55$, 群落下層では $0.12 \sim$ 0.18 となり, 群落内で下層に行くほぞ小さくなった. 一方, $\mathrm{B} / \mathrm{R}$ 比は群落上面で 0.56 0.58であったのに対し, 群落下 層でも $0.60 \sim 0.74$ と変化が小さかった. 群落中層と群落 下層に扮ける R/FR 比と B/R 比はいずれも, 南北の測定点 の違いによる顕著な差異はみられなかった.

\section{4 条植えでの中央条間の影響（実験 2)}

4 条植え摘心栽培に打ける中央条間が摘心後到花日数に 及ぼす影響を，通路に面した外側 2 条と中央条間に面した 内側 2 条に区分して第 7 図に示した。外側 2 条の摘心後到 花日数は中央条間によらず活汇一定であったが，内側 2 条 の摘心後到花日数は中央条間が狭くなる汪ど長くなった. その結果, 摘心後到花日数に打汀る外側 2 条と内側 2 条の 差（以下，内外差とする）は，中央条間が狭くなるほど大
第2 表 小ギク“翁丸’の群落内に打ける波長別光量子束密度

\begin{tabular}{|c|c|c|c|c|c|}
\hline \multirow{2}{*}{ 測定点 ${ }^{z}$} & \multicolumn{3}{|c|}{$\begin{array}{c}\text { 波長別光量子束密度 } \mathrm{y} \\
\left(\mu \mathrm{mol} \cdot \mathrm{m}^{-2} \cdot \mathrm{s}^{-1}\right)\end{array}$} & \multirow{2}{*}{$\begin{array}{c}\mathrm{R} / \mathrm{FR} \\
\text { 比 }\end{array}$} & \multirow{2}{*}{$\begin{array}{c}\mathrm{B} / \mathrm{R} \\
\text { 比 }\end{array}$} \\
\hline & $\begin{array}{l}\text { 青色光 } \\
\text { (B) }\end{array}$ & $\begin{array}{l}\text { 赤色光 } \\
(\mathrm{R})\end{array}$ & $\begin{array}{l}\text { 遠赤色光 } \\
(\mathrm{FR})\end{array}$ & & \\
\hline \multicolumn{6}{|l|}{ 群落上面 } \\
\hline 北側 & 23.2 & 41.1 & 39.2 & 1.05 & 0.56 \\
\hline 中央部 & 24.8 & 42.8 & 40.3 & 1.05 & 0.57 \\
\hline 南側 & 24.5 & 42.6 & 39.9 & 1.07 & 0.58 \\
\hline \multicolumn{6}{|c|}{ 群落中層（群落上面から $30 \mathrm{~cm}$ 下位） } \\
\hline 北側 & 6.9 & 11.1 & 16.6 & 0.54 & 0.62 \\
\hline 中央部 & 7.1 & 13.7 & 24.2 & 0.51 & 0.53 \\
\hline 南側 & 9.8 & 18.2 & 28.5 & 0.55 & 0.58 \\
\hline \multicolumn{6}{|c|}{ 群落下層（群落上面から $60 \mathrm{~cm}$ 下位） } \\
\hline 北側 & 0.2 & 0.2 & 2.0 & 0.13 & 0.74 \\
\hline 中央部 & 0.4 & 0.6 & 5.0 & 0.12 & 0.60 \\
\hline 南側 & 0.5 & 0.9 & 4.6 & 0.18 & 0.63 \\
\hline
\end{tabular}

2003 年 7 月 31 日（晴天日）の南中時に測定

$\mathrm{z}$ 北側，中央部扣よび南側の測定点は各々，北から 1 条目と 2 条目, 同 3 条目と 4 条目括よび同 5 条目と 6 条目の条間 $\mathrm{y}$ 青色光，赤色光报よび遠赤色光は各々，400～500，600 700 抽よび 700 〜 $800 \mathrm{~nm}$ として $10 \mathrm{~nm}$ ごとに測定した光量 子束密度を積算

きくなり，中央条間 $15 \mathrm{~cm}$ で最大の 3.8 日となった。一方， $75 \mathrm{~cm}$ 以上の中央条間では摘心後到花日数に内外差がみら れなかった。

中央条間が摘心後到花日数の斉一性と節数沶よび切り花 長に及ぼす影響を第 3 表に示した。到花日数については, 開花の集中程度を示す指標として開花盛期 5 日間に開花し た切り花本数を全切り花本数で除した割合（以下，5日率 とする）を算出した。 内外差を含めた摘心後到花日数は中 央条間が広くなるほど短くなり，開花の斉一性を示す５日 率は中央条間 $75 \sim 90 \mathrm{~cm}$ で $72 \sim 77 \%$ と高くなった。 節数 は，中央条間の違いと内外差のいずれに颃いても有意差が みられなかった。 


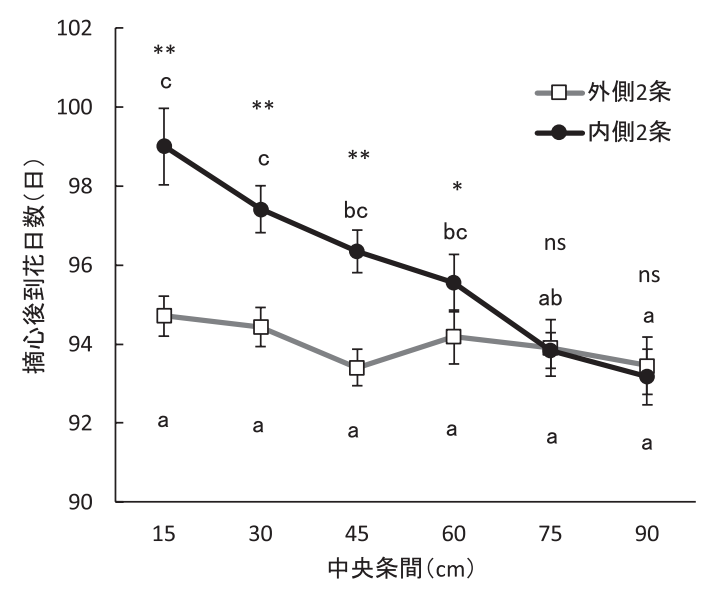

第 7 図 4 条植え摘心栽培した小ギク“翁丸’の中央条間が摘 心後到花日数に及ぼす影響

図中の䛊差範囲は，標準䛊差（n=24～32)

図中の**,*抢よびns はt検定により, 同一試験区内 の内側 2 条と外側 2 条の間に $1 \%, 5 \%$ 水準で有意差あ り，括よび有意差なしを示す

また, 異なる英小文字間に Tukey-Kramer の HSD 検定に より，5\%水準で有意差があることを示す

第 3 表 4 条植え摘心栽培した小ギク“翁丸’の中央条間が摘 心後到花日数の斉一性と切り花の節数に及ぼす影響

\begin{tabular}{|c|c|c|c|c|c|}
\hline \multirow[b]{2}{*}{ 中央条間 z } & \multicolumn{2}{|c|}{ 到花日数（日） } & \multicolumn{3}{|c|}{ 節数（節） } \\
\hline & 平均 & $\begin{array}{c}5 \text { 日率y } \\
(\%)\end{array}$ & 外 & 内 & 内外差 \\
\hline $15 \mathrm{~cm}$ & $97 \mathrm{c}$ & 53 & $36 a^{x}$ & $35 \mathrm{a}$ & ns. $^{\text {w }}$ \\
\hline $30 \mathrm{~cm}$ & $96 \mathrm{bc}$ & 60 & $34 \mathrm{a}$ & $35 \mathrm{a}$ & ns. \\
\hline $45 \mathrm{~cm}$ & $95 \mathrm{ab}$ & 67 & $36 \mathrm{a}$ & $36 \mathrm{a}$ & ns. \\
\hline $60 \mathrm{~cm}$ & $95 \mathrm{ab}$ & 60 & $35 \mathrm{a}$ & $36 \mathrm{a}$ & ns. \\
\hline $75 \mathrm{~cm}$ & $94 \mathrm{a}$ & 77 & $34 \mathrm{a}$ & $36 \mathrm{a}$ & ns. \\
\hline $90 \mathrm{~cm}$ & $93 \mathrm{a}$ & 72 & $34 \mathrm{a}$ & $34 \mathrm{a}$ & ns. \\
\hline
\end{tabular}

z 株間 $10 \mathrm{~cm}$, 条間 $15 \mathrm{~cm}$ の片側 2 条で，4 条植えとしたとき の中央条間

y 5 日率は，盛期 5 日間に開花した切り花本数を全切り花本 数で除した百分率

x 同一列の異なる英小文字間に, Tukey-Kramer の HSD 検定 により $5 \%$ 水準で有意差あり

${ }^{\mathrm{w}} \mathrm{ns}$. は，各中央条間での外側と内側の值に，t検定により $5 \%$ 水準で有意差がないことを示す（n=24～32）

\section{3. 植え付け条数と群落側面の遮光の影響（実験 3）}

植え付け条数と群落側面の遮光が栽植位置ごとの摘心後 到花日数に及ぼす影響を第 8 図に示した。 10 条区，10 条 遮光区拈よび 4 条区のいずれに打いても, 東西の通路に面 した各条で摘心後到花日数が短くなった. 一方, 10 条植 光の西から $2 \sim 8$ 条目の群落中央部ならびに 4 条植えの $2 \sim 3$ 条目にあたる内側の摘心後到花日数は, 100 日前後 でほぼ同等であった. 10 条遮光区では 10 条区と比べて, 西端の 1 条目で摘心後到花日数が長くなったが, 東端の 10 条目では差がみられなかった。各試験区に打ける摘心 後到花日数の斉一性と節数を第 4 表に示した. 摘心後到花
日数は97〜98 日の範囲で有意差がみられたものの，開花 斉一性を示す変動係数と 5 日率には大きな違いがみられ ず，節数にも差がなかった。

\section{4. 摘心の影響（実験 4）}

摘心の有無と仕立て本数が摘心後到花日数, 節数, 切り 花長および切り花重に及ぼす影響を第 5 表に示した。無摘 心区と比べて摘心栽培とした 2 区では，到花日数が短くな るとともに，その変動係数が小さく，5日率が高くなった. 節数, 切り花長および切り花重はいずれも摘心栽培とした 2 区で小さくなったが，摘心 1 本区と摘心 2 本区の間に各 測定項目とも有意差がみられなかった。

\section{考察}

本報では夏秋小ギクについて，キャベッ（藤原ら， 2003; 吉秋ら，2008）やトマト（吉岡ら，2000）など野菜 類と同様，機械化の前提となる一斉収穫を可能とするよう な開花斉一化を目指し，栽植様式とそれに伴う光環境の変 化が開花のばらつきに及ぼす影響を検討した。

実験 1 に打いて，6 条植えの群落として生育させた小ギ クの消灯後到花日数は南北方向の群落周縁部で短くなる一 方，中央部にあたる $2 \sim 5$ 条目の間には有意差がみられな かった（第 3 図）。また，実験 3 で南北 10 条植えの群落と して生育させた場合の摘心後到花日数も，東西の群落周縁 部で短くなる一方，中央部にあたる $2 \sim 8$ 条目の間には有 意差がみられなかった（第 8 図）。これらの結果は，群落 中央部では条ごとの到花日数の差が比較的小さく開花が揃 いやすいのに対し，群落周縁部の条では群落中央部と比較 して開花が早期化するため, 両者を合わせた群落全体とし ての開花斉一性を悪くしていることを示して扣り，周縁部 と中央部の到花日数を揃えることが開花斉一化のための重 要な課題であることが明らかとなった。

これら群落周縁部の切り花は, それより内側の切り花 と比較して節数に差がないものの, 切り花長が短く, 切り 花重が重くなる傾向がみられた（第1表）。これは，植物 群落で広く確認されている避陰反応や周縁効果（Smith, 1982；テイッ・ザイガー，2004）によるものと考えられる. 植物群落では草冠を構成する上位葉によって赤色光が多く 吸収され，群落内部での R/FR 比の低下がフィトクロム平 衡の変化を介して節間伸長を促し, 群落中央部の植物体の 草丈を長くする避陰反応を示す（Franklin・Whitelam, 2005; Smith, 1982). キクに括いても，遠赤色光の添加（Hisamatsu ら，2008; 島ら，2009） や除去 (Khattak ら，2004; Oyaert ら, 1999）によって節間伸長を制御できることが報告されてい る. 実験 1 に招いて, 群落内部の R/FR 比は群落の外側に あたる上面に比べて，中層执よび下層で大きく低下してお り(第 2 表)，先述のような避陰反応によって，群落の周 縁部と中央部に㧺ける切り花長の特徵的な差（第 1 表）が 生じたものと考えられる.な抏，本実験では土壤水分の調 査を行わなかったが，群落周縁部の切り花重が群落内部と 

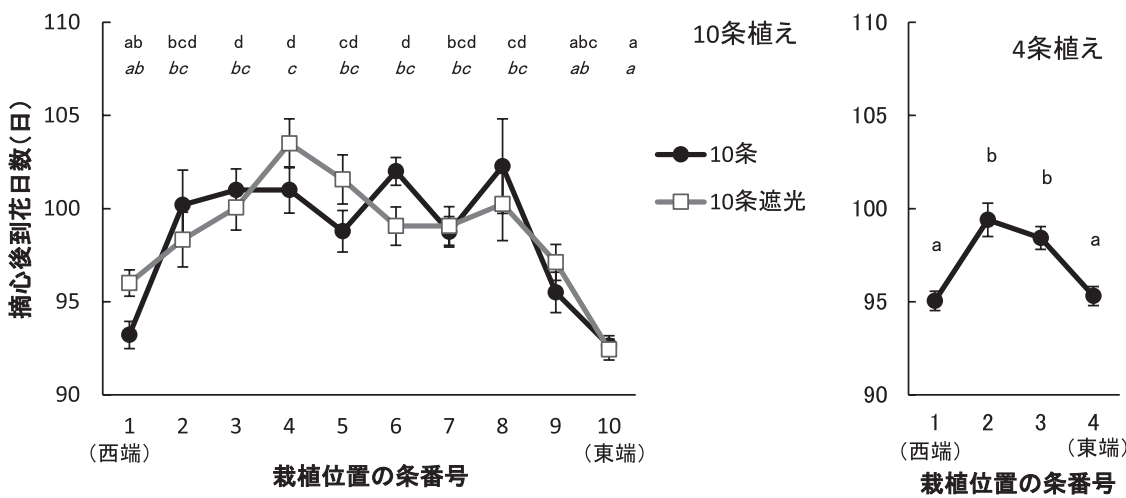

第 8 図＼cjkstart植光付け条数と群落側面の遮光が小ギク“翁丸’の栽植位置ごとの摘心後到花日数に及ぼす影響 䛊差範囲は標準誤差 $(\mathrm{n}=8 \sim 20)$

栽植位置は, 10 条もしくは 4 条の南北畧に打ける東西位置を西端から条番号で示した

試験区ごとに，異なる英小文字を付した条番号間には，Tukey-Kramerの HSD 検定により，5\%水準で有意差のあることを 示す

なお，立体は 10 条区，斜体は 10 条遮光区

第 4 表 植え付け条数と側面遮光が小ギク“翁丸’に扣ける摘 心後到花日数と節数に及ぼす影響

\begin{tabular}{lccccc}
\hline \hline & \multicolumn{4}{c}{ 摘心後到花日数 (日) } & \\
\cline { 2 - 5 } 処理区 $^{\mathrm{z}}$ & 平均 & $\begin{array}{c}\text { 標準 } \\
\text { 偏差 }\end{array}$ & $\begin{array}{c}\text { 変動 } \\
\text { 係数 }\end{array}$ & $\begin{array}{c}5 \text { 日率 } \\
(\%)\end{array}$ & $\begin{array}{c}\text { (節) } \\
\text { (\%) }\end{array}$ \\
\hline 10 条 & $98 \mathrm{ab}^{\mathrm{y}}$ & 5.7 & 5.3 & 41 & $35 \mathrm{a}$ \\
10 条遮光 & $98 \mathrm{~b}$ & 5.3 & 4.8 & 42 & $35 \mathrm{a}$ \\
4 条 & $97 \mathrm{a}$ & 4.8 & 4.5 & 46 & $35 \mathrm{a}$ \\
\hline
\end{tabular}

${ }^{\mathrm{z}} 10$ 条区は条間 $15 \mathrm{~cm}, 4$ 条区は条間 10-30（中央） $-10 \mathrm{~cm}$, いずれも株間を $10 \mathrm{~cm}$ とし摘心後, 株当たり 2 本仕立て

y 同一列の異なる英小文字間に Tukey-Kramer の HSD 検定に より，5\%水準で有意差のあることを示す（n=124～157）

${ }^{x} 5$ 日率は, 盛期 5 日間に開花した切り花本数を全切り花本 数で除した百分率

比較して同等以上となっている（第 1 表）ことから，灌水 頻度の不足で生じるょらな光合成能力の低下（後藤ら, 2002）は生じていなかったものと考兄られる.

次に，群落内位置が開花の早晚に及ぼす影響について は，光環境としてR/FR 比と PPFDの 2 つ違いが考えら れ，実験 1 の群落内部ではこれらが同時に変化していた。 すなわち，群落上面で $1.05 \sim 1.07$ の R/FR 比は群落中層で $0.51 \sim 0.55$ と低下していたが (第 2 表)，同時にPPFD も 大きく低下していた (第6図).R/FR 比に関しては，スプ レーギクに打いて FRを遮断するフィルムの被覆により光 合成有効放射を医涪同等とし，R/FR 比の久を 1.21 から 6.64 に変化させても開花期には影響しなかったと報告されてい る (Khattak ら, 1999, 2004).

一方PPFD 関してスプレーギクに扔いては，草冠が形 成された後の生育量が光合成有効放射によって高精度にモ デル化でき (Lee・Heuvelink, 2003), PPFDの増加によっ て短日下到花日数が短くなるとともに，その斉一性が高ま る（Karlssonら，1989）と報告されている. また， Langton ら（1999）は栽植密度の増加によって開花の斉一性が低下
第 5 表 摘心と仕立て本数が小ギク “翁丸’ の到花日数と節 数, 切り花長拈よび切り花重に及济寸影響

\begin{tabular}{|c|c|c|c|c|c|c|}
\hline \multirow[b]{2}{*}{ 処理区 ${ }^{z}$} & \multicolumn{3}{|c|}{ 到花日数（日）y } & \multirow{2}{*}{$\begin{array}{l}\text { 節数 } \\
\text { (節) }\end{array}$} & \multirow{2}{*}{$\begin{array}{l}\text { 切り } \\
\text { 花長 } \\
(\mathrm{cm})\end{array}$} & \multirow{2}{*}{$\begin{array}{c}\text { 切り } \\
\text { 花重 } \\
(\mathrm{g})\end{array}$} \\
\hline & 平均 & $\begin{array}{l}\text { 変動 } \\
\text { 係数 }\end{array}$ & $\begin{array}{c}5 \text { 日率 } \\
(\%)\end{array}$ & & & \\
\hline 無摘心 & $108 b^{x}$ & 4.59 & 38 & $51 \mathrm{~b}$ & $114 \mathrm{~b}$ & $98 \mathrm{~b}$ \\
\hline 摘心 $\cdot 1$ 本 & $104 \mathrm{a}$ & 4.14 & 70 & $34 \mathrm{a}$ & 96 a & $58 \mathrm{a}$ \\
\hline 摘心 $\cdot 2$ 本 & $104 \mathrm{a}$ & 4.09 & 66 & $36 \mathrm{a}$ & $93 \mathrm{a}$ & $53 \mathrm{a}$ \\
\hline
\end{tabular}

${ }^{\mathrm{z}} 3$ 区と夕条間 $15 \mathrm{~cm}$, 中央条間 $30 \mathrm{~cm}$ とした複 2 条の 4 条植 え，無摘心区と摘心 1 本区は株間 $7.5 \mathrm{~cm}$ ，摘心 2 本区は株 間 $15 \mathrm{~cm}$

$\mathrm{y}$ 無摘心区の到花日数は定植日から，摘心区の到花日数は 摘心日から起算

$\mathrm{x}$ 同一列の異なる英小文字間に Tukey-Kramer の HSD 検定に より，5\%水準で有意差のあることを示す（ $\mathrm{n}=37 ３ 8)$

することを報告して抢り，PPFDをめぐる競合が開花斉一 性に関わることが示唆されている，輪ギク“秀芳の力’の 電照栽培に扮いても，本間（1999）は葉数が多く，切り花 重の大きい群落周縁部のシュートで到花日数が短くなると 報告している. 実験 1 亿打いて子消灯時節数が多く, 切り 花重の重い切り花ほど到花日数が短くなる負の相関（第 5 図）がみられて打り，本間（1999）の報告と同様の結果と なった．これらのことから，群落の中央部に比べて周縁部 では切り花重の増加（第 1 表）と開花の早期化（第 3 図） といら2つの現象が生じていたが，これらは共通して群落 周縁部での PPFD が相対的に多いことによって引き起こさ れたものと推察される。

また実験 1 と打いて，群落中央部 $3 \sim 4$ 条目の条間での PPFD は，群落周縁部にあたる南側 $5 \sim 6$ 条目および北側 $1 \sim 2$ 条目の条間と比較して，群落上層で同等かやや少な く，群落中層で逆に多くなっており（第6図）群落中央部 で群落内のより下層まで光の入りやすい群落構造となって いたことが示唆された。こうした群落構造は，群落中央部 
の生育・開花に打牧斉一性に寄与した可能性が考兄られ るものの，その検証には群落内に打けるPPFDの水平分布 をより詳細に調查する必要があうう。また，こうした群落 構造に関わる要因については, 佐本ら（1979）が指摘した よらに葉面積や葉の着生角度なぞが考兄られるが，これら についても今後, 品種間差を含めて精査していく必要があ る. な扔, 南側の上層で午前中の光量が大きかった点につ いては, 本報で用いた施設の区画上, 群落を形成させた栽 培ベッドが正確な東西方向ではなく, やや東北東から西南 西に配置されたため午前中の日射の影響が群落南側でより 強く現れたものと考光られた。

これらの結果をふまえ, 群落の周縁部と中央部の開花を 揃える試みとして, 実験 2 では中央条間を拡げることで群 落中央部の光環境を改善する方法を, 実験 3 では群落中央 部にあたる条数を増やすとともに群落周縁部を遮光する方 法を検討した.

実験 2 に打いて内側の到花日数は中央条間を拡げること によって外側の到花日数に近づき(第 7 図), “秀芳の力’ の電照抑制作型に扔いて 4 条植えの中央条間を拡げること で開花がより斉一化されたとする報告（本間，2000）と同 様の結果となった. このことは群落中央部の光環境の改善 が開花斉一化に大きく寄与することを示す結果ではある が，外側と内側の到花日数の差を完全になくすためには条 間 $75 \mathrm{~cm}$ 以上（第 7 図）と 1 条植えに近い栽植様式が必要 となり，圃場面積当たり収量の減少を伴うこととなる.

一方, 植光付条数を増やすとともに群落周縁部の遮光 を行った実験 3 では, 群落周縁部の到花日数が長くなり, 群落中央部の到花日数にやや近づいた（第 8 図）ものの, その変動係数の改善効果は小さかった（第 4 表）。また， 副次的な問題点として 10 条植えとした実験 3 では, 畧内 部への農薬散布や整枝, フラワーネットの管理などに手間 取る場面も多く，作業性に問題が見られた。本稿で割愛し た他の作型，品種および遮光資材を用いた実験に扔いても 同様の結果となって扣り, 群落周縁部の遮光の久によって 群落周縁部の開花を遅らせ, 群落中央部の開花に揃兄る方 向での開花斉一化は難しいものと考兄られた。 また本実験 に颃いては, 遮光の有無にかかわらず群落周縁部で通路側 を遮蔽するよらに葉が下垂して着生する様子が観察されて 扣り，通路幅の縮小など入射光の方向を含めて調節する手 法を考慮する必要があるものと考兄られた。

カーネーションでは, 栽培ベッドに $2 \sim 8$ 条で栽植する 際の株配置が収量と品質に及洔す影響が古くから検討され て抢り, 通路側からの光が茎による遮蔽と葉による吸光に よって失われるため, 群落周縁部と中央部に収量差が生じ るとされている(三浦，2012），そのため，8条植えより も中央部 2 条に栽植せず中央条間を広く取る 6 条植えで収 量と品質の両面が優れ（米村・樋口, 1977), さらに養水 分を均一管理できる灌水同時施肥栽培の条件下では, 栽植 密度が同一の 2 条並木植えとすることで開花の斉一性も高
まる（山中ら，2011）とされている.

これらのことから，露地作が主体の小ギク生産に捻いて も畧中央の条間を拡げて群落中央部の生育を改善するとと もに，通路幅や畝間の縮小によって通路をはさんで隣接す る両側の畧に植栽された株同士の距離を近づけ，久かけ上 の 1 条植えに近づける方向性が現実的だと考觉られる。こ の栽植様式は, 奇しくも東日本の一部で行われている 1 条 植え摘心栽培に近づくこととなるが，この慣行 1 条植え栽 培では, 通路幅が他の畑作物に準じて $60 \sim 80 \mathrm{~cm}$ と広い ため戒場面積当たり立茎数が $2 \sim 3$ 千本・ $\mathrm{a}^{-1}$ と少ない。こ れに対し，慣行の畧形状をできるだけ変更せずに，通路を はさんだ外側条同士の距離と中央条間が同じになるような 栽植様式を実験 3 の 4 条植光摘心 2 本仕立てに準じて試算 すると，畧間 $130 \mathrm{~cm}$ ，株間と片側 2 条の条間をともに $12 \mathrm{~cm}$, 中央条間を $53 \mathrm{~cm}$ とする改善策によって戋場面積 当たり立茎数は 5.1 千本・ $\mathrm{a}^{-1}$ となり, 西日本の慣行 2 条植 光摘心栽培に括汀る 5.3 千本・ $\mathrm{a}^{-1}$ に近い固場面積当たり立 茎数が見込める。 このよらな現状の畧形状に近い栽植様式 であれば，畧を跨ぐ形式の収穫機（田中，2012; 山本ら， 2014）の戋場内運行を容易にできる利点も期待できるた め, 今後より実証的な検討を進める必要があるものと考光 られる。

一方で, 露地小ギク生産と比べて風や病害虫の問題が少 なく管理作業が容易となる大規模施設内であれば, 先述し たように, 群落周縁部を減らして可能な限り多条植えにす るといら方向性も，圃場全体の開花斉一性を高める手法と なり得るものと考光られる。しかし，この場合にはスプ レーギク（Langtonら，1999）と同様，小ギクに拈いても， 品種や季節の日射量ごとに適正な栽植密度も再検討する 必要があり, 施設化と併せた将来的な検討課題の一つとい える.

また，実験 1 の摘心後分枝の発生位置では上位節と中位 節の消灯後到花日数の差は小さく，下位節でその分散が拡 大した (第 4 図)。実験 4 では無摘心栽培よりも摘心栽培 で開花斉一性が高まったが, 摘心 1 本仕立てと摘心 2 本仕 立てに差はみられなかった (第 5 表)。これらより開花斉 一化のためには, 無摘心栽培よりも摘心栽培とし, 株当た りの仕立本数を 2 本までにすることが望ましいと考光られ た. 親株からの挿し穂の採穂位置など苗の来歴は開花の分 散に影響する（仲ら，2016）が，無摘心栽培に比べて摘心 栽培では, こうした苗に由来する開花の分散を小さくする ことができたものと考光られる。また，佐本ら（1979）は “弥栄”など 3 品種の秋ギクを用いて切り花品質の均一性 と一株仕立て本数の関係を検討し，下位分枝の成長が遅孔 て弱小となることから，上級品比率の変わらない 3 本を許 容限度とした．夏秋ギク型小ギクを用いた実験 1 亿括ける 下位分枝で開花が遅れる傾向（第4図）は佐本ら（1979） と同様であったが，開花斉一性の視点から久た適正な仕立 て本数は 2 本以下と少なくなった. この結果は, 西日本の 
慣行 2 条植光摘心栽培と同等の圃場面積当たり立茎数であ るにもかかわらず，手作業での一斉收穫が行われている沖 縄県に招いて，4条植光摘心 2 本仕立てが広く普及してい る要因の一つだと推察される.

これらのことから, 群落として生育させた小ギク切り花 の開花斉一性には群落内での栽植位置と摘心後分枝位置が 影響しており, 中央条間を拡げることや摘心後分枝を 2 本 以下に制限することによって，開花斉一性が高まることが 示された. しかし，本報の各実験は “翁丸”のみを用いて 行った結果であり, 品種固有の葉の形態などに由来する品 種間差（仲ら，2007）については考慮できていない. 多品 種の組み合わせによって長期間の連続出荷が行われている 露地小ギク生産へ適用するには, それらの比較検討が今後 の課題として残されている.

\section{摘 要}

収穫機による一斉収穫を目指して, 栽植様式が開花斉一 性に及ぼす影響を，夏秋ギク型小ギク “翁丸’を用いて検 討した. 6 条 7 列の群落として栽培した小ギク切り花につ いて，栽植位置扣よび摘心後分枝の発生節位ごとの到花日 数を調査した. 到花日数は群落中央部の 4 条間では差がな く，通路に面した南北の周縁部で短くなった．群落中央部 の PPFD は周縁部に比べて, 草冠部に相当する上層とそこ から約 $15 \mathrm{~cm}$ 下位の中層との差が小さく, より下位葉まで 日射が到達していた。 また，株当たり 3 本整枝とした摘心 後分枝の発生節位では，上位節および中位節と比較して下 位節で到花日数が長くなり，そのばらつきも大きかった. こらした群落内での栽植位置による到花日数の差を小さく するため, 中央条間の変更, 群落周縁部の遮光および摘心 の影響を検討した. 南北喃の 4 条植え群落における中央条 間を $15 \sim 90 \mathrm{~cm}$ まで変化させ，内側 2 条と外側 2 条の到花 日数を比較すると, 到花日数の内外差は中央条間が広い注 ど小さくなり，75 cm 以上ではみられなくなった。また， 10 条植え群落に打いて遮光率 $31 \%$ の遮光資材を通路に面 した群落側面に下垂させて到花日数を調査した. 遮光処理 によって群落周縁部の到花日数はやや長くなったものの, 群落全体の開花斉一性は高まらなかった。 さらに 4 条植え 群落に扣いて，無摘心と摘心後 1 本もしくは 2 本仕立てと した 3 区の到花日数を比較したところ, 摘心栽培の 2 区で 開花斉一性が向上した。 これらから, 小ギク切り花の開花 斉一性には群落内での栽植位置と摘心後分枝位置が影響し て扣り, 中央条間の拡大と摘心後分枝数の制限によって改 善できることが示された.

\section{引用文献}

天野哲郎．2006. 大規模畑作経営に打ける野菜作の展開と キャベッ機械収穫システムの経営評価. 農機誌. 68 : 9-13.

青木 循. 2013. 新型キャベッ収穫機. 農機誌. 75: 239-
241.

Franklin, A. K. and G. C. Whitelam. 2005. Phytochromes and shade-avoidance responses in plants. Annals of Botany. 96: 169-175.

藤原隆広・吉岡 宏・熊倉裕史・佐藤文生・中川 泉. 2003. キャベツの品種, 作型拈よび栽植距離が収穫時 の生育の斉一性に及ぼす影響. 園学研. 2: 109-114.

藤原隆広・吉岡 宏・佐藤文生. 2000. 栽植密度と定植後 の苗の初期生育がキャベッ生育の斉一性に及ぼす影 響. 園学雑. 63: 315-322.

Fukumoto, Y., T. Hamada, J. Suyama, A. Yamamoto and T. Naka. 2011. Development of flowering stage inspection equipment for small-flowered chrysanthemum. J. Robotics and Mechatronics. 23: 310-315.

後藤丹十郎・松野太樹・吉田裕一・景山詳弘. 2002. 根域 制限下で栽培したキクの光合成，蒸散特性と葉の形態 に及ぼす養水分供給頻度の影響. 園学雑. 71: 277283.

Hisamatsu, T., K. Sumitomo and H. Shimizu. 2008. End-of-day far-red treatment enhances responsiveness to gibberellin and promotes stem extension in chrysanthemum. J. Hort. Sci. Biotech. 83: 695-700.

本間義之. 1999 . キクの摘葉処理による到花日数の集中 化. 園学雑. 68 (別 2) : 383 .

本間義之. 2000. 植兄付け条間の改変によるキクの到花日 数の集中化. 園学雑. 69 (別 1) : 325 .

池田 広・今村 仁・岡本章秀. 2006. 栽植密度がキクの 生育, 切り花形質に及ぼす影響. 園学雑. 75 (別 1): 381.

Karlsson, G. M., R. D. Heins, J. E. Erwin, R. D. Berghage, W. H. Carlson and J. A. Biernbaum. 1989. Irradiance and temperature effects on time of development and flower size in chrysanthemum. Scientia Hort. 39: 257-267.

川田䅣一・豊田 努・宇田昌義・沖村 誠・柴田道夫・亀 野 貞・天野正之・中村幸男・松田健雄. 1987. キn の開花期を支配する要因. 野菜茶試研報 A. 1: 187222.

Khattak, M. A., S. Pearson and C. B. Johnson. 1999. The effects of spectral filters and nitrogen dose on the growth of chrysanthemums (Chrysanthemum morifolium Ramat., cv. Snowdon). J. Hort. Sci. Biotech. 74: 206-212.

Khattak, M. A., S. Pearson and C. B. Johnson. 2004. The effects of far red spectral filters and plant density on the growth and development of chrysanthemums. Scientia Hort. 102: 35341.

Langton, A. F., L. R. Benjamin and R. N. Edmondson. 1999. The effects of crop density on plant growth and variability in cut-flower chrysanthemum (Chrysanthemum morifolium Ramat.). J. Hort. Sci. Biotech. 74: 493-501. 
Lee, H. J. and E. Heuvelink. 2003. Simulation of leaf area development based on dry matter partitioning and specific leaf area for cut chrysanthemum. Annals of Botany. 91: 319-327.

三浦泰昌. 2012. 大輪系品種の光合成特性を基にした栽培 法の研究. p.91-146. 温室カーネーションの施肥, 光 合成と栽培法の研究. 東京農大出版会. 東京.

仲 照史. 2011。 一斉収穫など収穫作業の機械化. p. 3643. 大石一史編著. キクをつくりこなす。農文協. 東 京.

仲 照史・濱田敏弘・松本由利子・福本靖彦・印田清秀・ 後藤丹十郎. 2014. 小ギク切り花の開花程度選別を機 械化するための計測手法. 植物環境工学. 26: 145153.

仲 照史・角川由加 - 前田茂一・後藤丹十郎. 2016. 夏秋 小ギクの開花斉一性向上に打ける親株系統選抜の重要 性. 園学研. 15: 39-46.

仲 照史・角川由加・前田茂一・竹㟝あかね. 2007 . 夏秋 小ギクに打ける開花斉一性と着葉形態の品種間差異. 園学研. 6(別 2): 359 .

中村恵章・野村浩二・加藤裕文・山田良三. 2008. 露地小 ギク栽培の短茎規格に適した栽植密度と施肥法. 愛知 農総試研報。40: 191-199。

Oyaert, E., E. Volckaert and P. C. Debergh. 1999. Growth of chrysanthemum under colored plastic films with different light qualities and quantities. Scientia Hort. 79: 195-205.

佐本啓智・中川 修・大西謙二. 1979．栽培条件に対寸る キクの生態反応に関する研究— 1 キクの栽植密度・ 一株仕立本数. 野菜試報 A. 5: 119-144.

島 浩二・川西孝秀 - 山田 真 - 石渡正紀 - 住友克彦 - 久 松 完. 2009. 明期終了時の短時間遠赤色光照射が冬 季に打けるスプレーギクの茥伸長に及ぼす影響. 園学
研. 8: 335-340.

Smith, H. 1982. Light quality, photoperception, and plant strategy. Ann. Rev. Plant Physiol. 33: 481-518.

角川由加・仲 照史・前田茂一．2007．暗期中断およびエ セフォン処理による小ギクの開花抑制程度の品種間差 異一計画的な 8 月上旬出荷適応品種の検索．奈良農総 七研報. 38: 47-51.

田中宏明. 2012. 一斉開花栽培に対応した小ギク収穫機. 農機誌. 74: 99-101.

テイッ，L.・E.ザイガー. 2004. フィトクロムと光による 植物の発生制御. p. 381-393. 西谷和彦・島崎研一郎 監訳. 植物生理学第 3 版. 培風館. 東京.

富山あずさ. 2012. 生産者事例・沖縄県 $11 ＼mathrm{~ 月 ~ 月 出 荷 ・ ~}$ 小ギク。p. 636 の 2-7. 農業技術体系花卉編 6 キク（ク リサンセマム)。農文協. 東京.

山本 明・陶山純・本荘絵未. 2014. 農産物の収穫機. 特許第 5467235 号.

山本健司. 1997. キャベッ収穫機. 農機誌. 59: 147-149. 山中正仁・後藤丹十郎・東浦 優. 2011. スプレーカー ネーションの灌水同時施肥栽培に扣ける栽植方式が収 量执よび切り花品質に及ぼす影響. 岡山大農学報. 100: $31-37$

米村浩次・樋口春三. 1977. シム系カーネーションの栽植 密度について。愛知農総試研報。B9: 74-78.

吉秋 斎・佐藤隆徳・亀野 貞・鈴木 徹・畠山勝徳・石 田正彦. 2008. 機械収穫に適したキャベッ品種の選定 と特性の評価. 野菜茶研報. 7: 37-43.

吉岡 宏・佐藤文生・藤原隆広．2000．側枝 2 本仕立て一 段果房栽培と房どり収穫による生食用トマトの省力・ 機械化栽培様式の開発. 農作業研究. 35: 189-197. 